\title{
ESTABLISH THE INITIAL PROCEDURE FOR DETECTING VIBRIO PARAHAEMOLYTICUS IN THE SHRIMP BY ONE STEP- PCR METHOD
}

\author{
THI-HUYEN TRAN ${ }^{1}$, HOANG-ANH PHAN THI ${ }^{1}$, LOC TRAN $^{2}$ \\ ${ }^{I}$ Institute of Biotechnology and Food-technology, Industrial University of Ho Chi Minh city, \\ ${ }^{2}$ Faculty of Fisheries, Nong Lam University, Vietnam.
}

\begin{abstract}
Early Mortality Syndrome (EMS), also known as Acute Hepatopancreas Necrosis Disease (AHPND) in shrimps, has been identified as being caused by a strain of $V$. parahaemolyticus. This disease has caused enormous damage to the shrimp farming industry among countries in the world in general and Vietnam in particular. One of the main reasons for uncontrollable widespread disease is the process of identifying pathogens is slow and inaccurate, leading to no promptly preventive measurement. In order to enhance the ability to briefly detect disease and improve the current disease status, in this study the PCR process using two specific 16S rRNA and ldh primers has been developed to swiftly diagnose $V$. parahaemolyticus pathogen in shrimps with a detection threshold of $3.5 \times 10^{3} \mathrm{CFU} / \mathrm{ml}$.
\end{abstract}

Keywords. Vibrio parahaemolyticus, Shrimp, Vietnam, PCR.

\section{INTRODUCTION}

Early Mortality Syndrome (EMS) was originally classified as a spontaneous disease because there was no definitive pathogen. In the three-year research period from 2011 to 2013, in Vietnam, the experts in departments including Ministry of Agriculture \& Rural Development, OIE, international organizations (World Bank, FAO, GAA), a number of businesses and The University of Arizona (USA) had jointly formed a research team that led by professor Donal Lightner. The research team isolated the main agent causing AHPND in shrimps as a strain of $V$. parahaemolyticus [1]. Shrimps after infection have manifestations such as lethargy, empty intestine, limp body, pancreatic liver. Based on the identified causative agent and the manifestations of diseased shrimp, EMS has proposed a name that is Acute Hepatopancreas Necrosis Disease (AHPND) [1].

AHPND, which occurred in 2009, began to cause damage in southern China by causing massive deaths of giant tiger prawn and white shrimp [1]. AHPND has appeared in Vietnam in 2010, in Malaysia in 2011 and in Thailand in 2012 [1]. In Vietnam, AHPND has first appeared in the Mekong River Delta region. In the two consecutive years (2011 and 2012), the disease continued to spread to many other provinces, especially Tra Vinh, Soc Trang, Kien Giang and some coastal provinces in the North and North Central. It can be estimated that in Vietnam there was a loss of about 500 million USD due to this disease in 2011 and 2012. According to the report of the Department of Animal Health in Vietnam, the area of infected shrimp in the Mekong River Delta is 39,000 hectares in the year 2011 and 2012. Therefore, it is necessary to have timely measures to prevent the spread of disease on a large scale, which is also the reason why we built and implemented the topic "Building the procedure for detecting a variety of Vibrio parahaemolyticus in the shrimps by PCR" to contribute to the detection of AHPND in a simple, fast and promptly manner.

Pathogen from $V$. parahaemolyticus depends on the presence of virulence agents including lecithin hemolysin (LDH), thermolabile hemolysin (TLH), thermostable direct hemolysin (TDH) and TDHrelated hemolysin (TRH) [2]. Therefore, only a few strains of these bacteria have been shown to cause 
AHPND [3]. Among them, the gene ldh has been shown to be a specific gene for this bacterium [4]. Being is a phospholipase that hydrolyzes both fatty acid esters of phospholipids, hydrolyzing phosphatidylcholine (PC) into lysophosphatidylcholine (LPC) and then hydrolyzes LPC to glycerophosphorylcholine (GPC) [5]. Moreover, LDH protein is purified from the culture of $V$. parahaemolyticus considered such as a toxin capable of activating the hemolytic factor of this bacterium [5]. In addition, the $16 \mathrm{~S}$ gene has demonstrated to exist in most of pathogenic $V$. parahaemolyticus[1]. Relying on that, we decided to collect two primers both16S rRNA gene and $l d h$ toxin gene to study one PCR procedure for precise and specific detection of V.parahaemolyticus caused AHPND in shrimp in Vietnam, and then finding the threshold for detection of $V$. parahaemolyticus rely on identified PCR procedure.

\section{MATERIALS AND METHODS}

This study was carried out in the biomolecular lab of the Institute of Biotechnology and Foodtechnology.

\subsubsection{V.parahaemolyticus strains used}

Three different bacteria used in this study comprises $V$. parahaemolyticus causing AHPND (provided by Research Institute For Aquaculture No2); V. parahaemolyticus bacterial genome (accession number AF388387.1) was isolated and obtained from diseased shrimp, supplied by Doctor Tran Huu Loc of Nong Lam University [1]; and strain of V. parahaemolyticus ATCC 17802.

\subsection{Methods}

\subsubsection{Culture $V$. parahaemolyticus strains}

The two pathogenic $V$. parahaemolyticus and V. parahaemolyticus ATCC 17802 which were preserved in $50 \%$ glycerol solution at $-50^{\circ} \mathrm{C}$ are restored in TSB medium supplemented with $2 \% \mathrm{NaCl}$ at $28^{\circ} \mathrm{C}$ for 18 hours. Subsequently, the inoculated bacterial cultures are spread to the TSA medium supplemented with $2 \% \mathrm{NaCl}$. Next, the media plates are incubated at $37^{\circ} \mathrm{C}$ for 24 hours for bacterial growth. The individual colonies of bacteria are suspended in $10 \mu \mathrm{l}$ of deionized water and then $1 \mu \mathrm{l}$ is taken to perform PCR.

\subsubsection{Optimization of the PCR protocol}

To access the specificity of the PCR procedure, two specific primers for 16S rRNA gene and ldh gene were used. Then, for optimizing the basic PCR protocol to detect $V$. parahaemolyticus from AHPND diseased shrimp in Vietnam, a gradient of annealing temperature from $50^{\circ} \mathrm{C}$ to $65^{\circ} \mathrm{C}$ was prechecked to finding the best proper one for PCR protocol. From differences in gel results, we discovered only one annealing temperature of $52^{\circ} \mathrm{C}$, both bands presented for two particular genes appeared together in agarose gel electrophoresis. After that, the thermal cycle was carried out with the following procedure: denaturation at $94^{\circ} \mathrm{C}$; annealing with 30 thermal cycles of $94^{\circ} \mathrm{C}$ for 30 seconds, $52^{\circ} \mathrm{C}$ for 30 seconds and $70^{\circ} \mathrm{C}$ for 60 seconds; elongation for 10 minutes at $70^{\circ} \mathrm{C}$; final hold and preservation of the PCR product samples at $4^{\circ} \mathrm{C}$. 
Table 2.1: Primers used for amplification of the ldh [4] and 16S rRNA genes [1].

\begin{tabular}{ccc}
\hline Genes & Primer sequences & Amplicon Size \\
16S rRNA & F: 5'-GCCT AACACATGCAAGTCGA-3' & $770 \mathrm{bp}$ \\
& R: 5'-GACTACCAGGGTATCTAATCC-3' & \\
$l d h \quad l d h$-F: 5'-AAAGCGGATTATGCAGAAGCACTG-3' & $448 \mathrm{bp}$ \\
\hline
\end{tabular}

Table 2.2: PCR reaction mixture composition

\begin{tabular}{ccc}
\hline Brands & Reagents & Volume $(\mu \mathrm{L})$ \\
\hline $\begin{array}{c}\text { New England } \\
\text { Biolabs }\end{array}$ & PCR Taq Master Mix 2X & 12.5 \\
& Forward primers $(10 \mu \mathrm{M})$ & 0.5 \\
Reverse primers $(10 \mu \mathrm{M})$ & 0.5 \\
Water & 10.5 \\
DNA & 1
\end{tabular}

\subsubsection{Method of determining the threshold of detection of pathogens by PCR}

The individual colonies of bacteria were cultured for growth in the TSB medium supplemented with $2 \% \mathrm{NaCl}$ shaking at $28^{\circ} \mathrm{C}$ for 18 hours until $\mathrm{OD}_{600}$ reaches 0.6 . After that, the proliferation was continuously diluted down to 10 times to obtain a range of different bacterial density. Bacterial density was determined by spreading $100 \mu \mathrm{l}$ of diluent to TSA medium supplemented with $2 \% \mathrm{NaCl}$ incubated at $37^{\circ} \mathrm{C}$ for 24 hours for colony growing before counting colonies. At the same time, the diluents were centrifuged for cell sedimentation at 3500rpm and $4^{\circ} \mathrm{C}$ for 5 minutes. After following that step, PCR protocol was performed. The detection threshold was defined as the lowest bacterial density that this PCR method can detect.

\section{RESULTS}

\subsection{Detection of genes 16S rRNA and $l d h$ on pathogenic bacterial genomes}

To build the process of detecting $V$. parahaemolyticus, we relied on the presence of 16S rRNA and $l d h$ genes. In particular, 16S rRNA has been published to appear on pathogenic bacteria in Vietnamese shrimps, and the $l d h$ toxin gene is present in all $V$. parahaemolyticus bacteria isolated from specimens and in the environment, but it does not exist in other Vibrio species [6]. In addition, a study of the bacterium $V$. parahaemolyticus isolated from shrimps in Thailand was found that the presence of the ldh gene in all shrimp samples that had the acute hepatopancreas necrosis disease, whereas both genes of $t d h$ and $t r h$ at the same time yielded negative PCR results. Moreover, the $l d h$ gene has refined about its presence on $V$. parahaemolyticus ATCC 17802 strain, thus we collected and use a V. parahaemolyticus ATCC 17802 strain as a positive control. As shown in Figure 3.1, two bands of PCR products that existed in agarose gel 
show the genome of the pathogenic bacteria contains 16S rRNA and $l d h$ genes simultaneously. Based on that data, we decided to use this bacterial genome as a positive control for subsequent experiments.

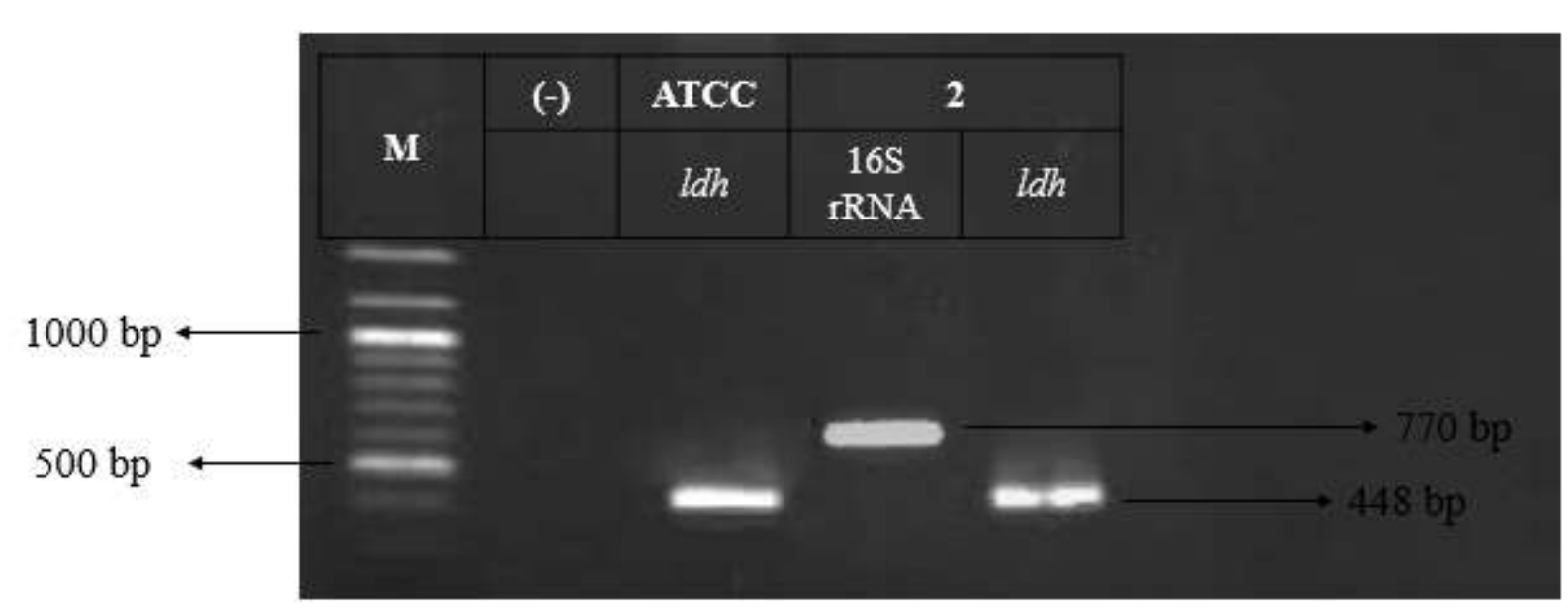

Figure 3.1: Agarose gel with PCR amplification products specific for the ldh and 16S rRNA genes on the genome of the bacterial causes disease. M: Marker. (-): Negative control (water). ATCC: V. parahaemolyticus ATCC 17802. 2: The genome of the bacterial causes disease (AF388387.1).ldh: PCR products with ldh-specific primers. $16 \mathrm{~S}$ rRNA: PCR products with $16 \mathrm{~S}$ rRNA-specific primers.

\subsection{Detection of 16S rRNA gene and $l d h$ gene on $V$. parahaemolyticus causing AHPND}

We continued to determine directly on pathogenic bacteria based on the PCR procedure described above. The results in Figure 3.2 show that PCR results also successfully amplified two segments of 16S rRNA and $l d h$ genes in positions of $770 \mathrm{bp}$ and $448 \mathrm{bp}$ respectively. These revealed two primers are specific for amplifying both two target genes (16S rRNA and ldh) [4], [1]. Therefore, this PCR method can be used to detect the presence of two genes 16S rRNA and $l d h$ on pathogenic bacteria on Vietnamese shrimps.

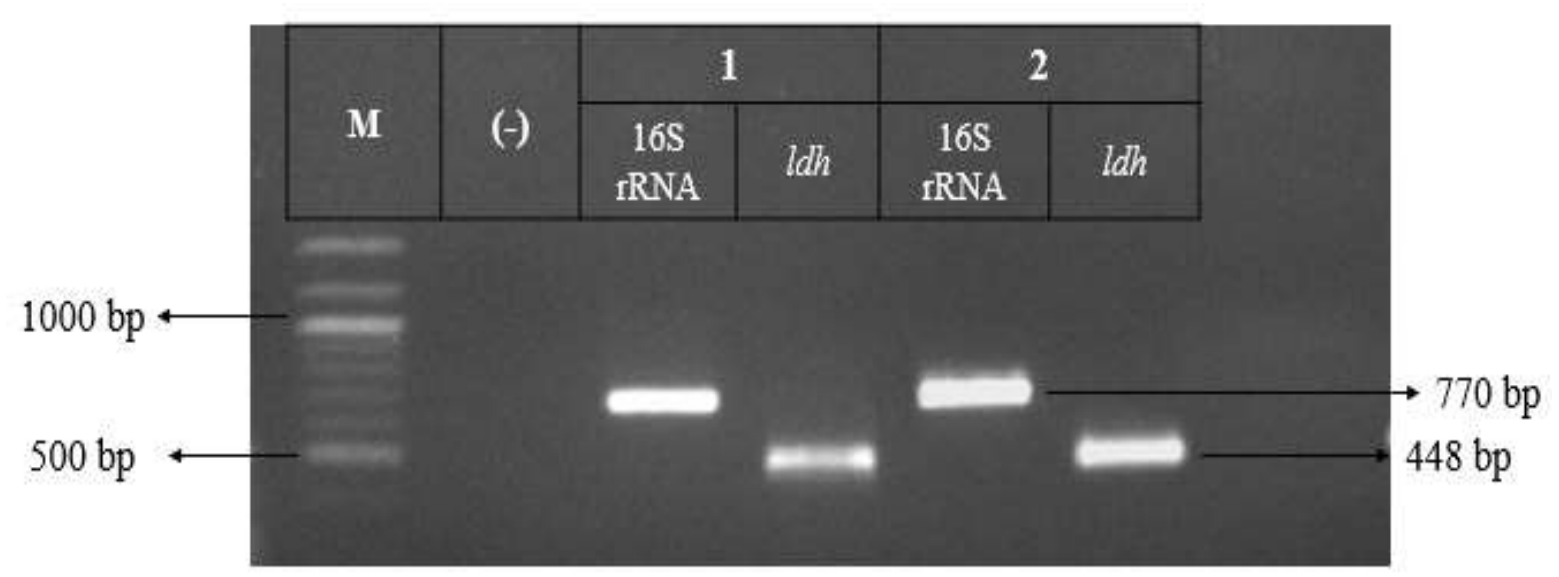


Figure 3.2.Agarose gel with amplification products of two specific primers $16 S$ rRNA and ldh. M:

Marker. (-): Negative control (water). 1: Genome V. parahaemolyticus causes disease in shrimp (positive control). 2: Bacteria V. parahaemolyticus. $16 S$ rRNA: PCR products with $16 S$ rRNA-specific primers.

ldh: PCR products with ldh-specific primers.

\subsection{Threshold for detecting pathogens by PCR}

After establishing the detection procedure for $V$. parahaemolyticus using PCR method, we determined the detection threshold of this method. According to the results (Figure 3.3), there are two electrophoresis bands of $16 \mathrm{~S}$ rRNA and $l d h$ corresponding to 770bp and 448bp positions with a decrease in density from bacteria density $3.7 \times 10^{10}$ to $3.5 \times 10^{3} \mathrm{CFU} / \mathrm{ml}$. At the density of $2 \times 10^{2}$ bacteria, only the fuzzy electrophoresis band at the position of $16 \mathrm{~S}$ rRNA is also described.
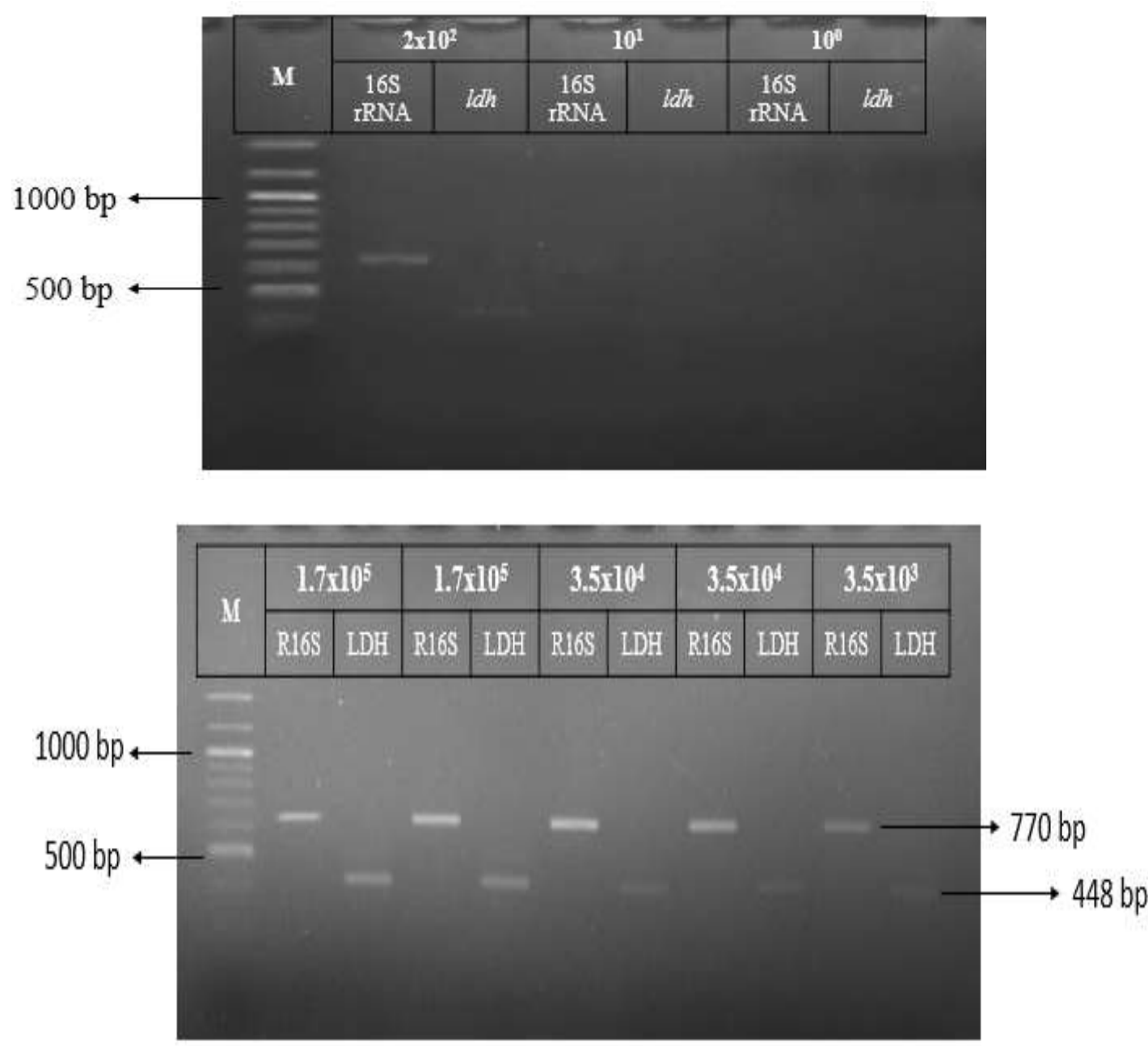


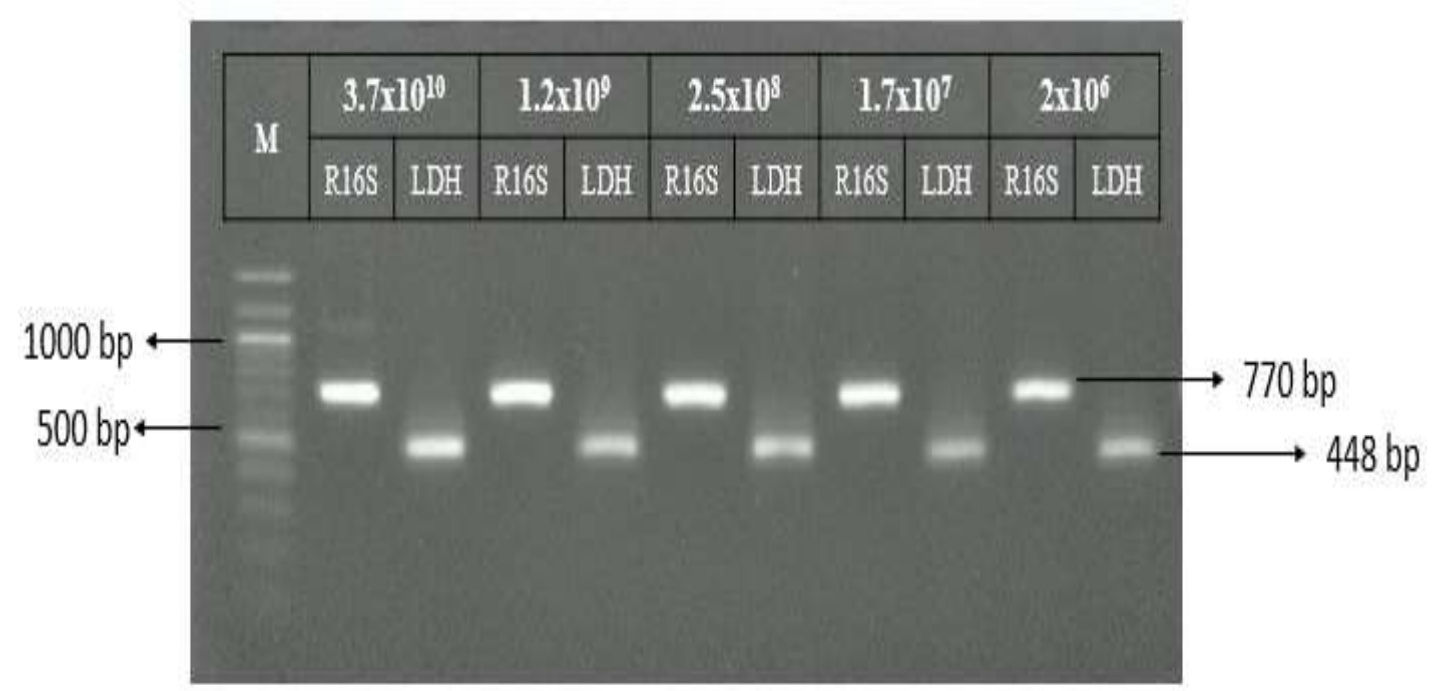

Figure 3.3.Agarose gel with amplification products specific primers at bacteria density $3.7 \times 10^{10}$ to $10^{\circ}$. A: Density from $3.7 \times 10^{10}$ to $2 \times 10^{6} \mathrm{CFU} / \mathrm{ml}$. B: Density from $1.7 \times 10^{5}$ to $3.5 \times 10^{3} \mathrm{CFU} / \mathrm{ml}$. C: Density from $2 \times 10^{2}$ to $10^{\circ}$ CFU/ml. M: Marker. $16 \mathrm{~S}$ rRNA: PCR product with $16 \mathrm{~S}$ rRNA-Specific primers, ldh: PCR products with

ldh specific primers

These results are summarized in Table 3.1, and the detection threshold of PCR method is $3.5 \times 10^{3} \mathrm{CFU} / \mathrm{ml}$.

Table 3.1: Validation of PCR based test for simutaneous detection of bacterial density from $3.7 \times 10^{10}$ to $10^{\circ}$ of V. parahaemolyticus. “+”: Positive results. “-”: Negative results.

\begin{tabular}{|c|c|c|c|c|c|c|c|c|c|c|c|}
\hline & \multicolumn{11}{|c|}{ Cell density (CFU/ml) } \\
\hline & $10^{0}$ & $10^{1}$ & $2 \times 10^{2}$ & $3.5 \times 10^{3}$ & $3.5 \times 10^{4}$ & $1.7 \times 10^{5}$ & $2 \times 10^{6}$ & $1.7 \times 10^{7}$ & $2.5 \times 10^{8}$ & $1.2 \times 10^{9}$ & $3.7 \times 10^{10}$ \\
\hline $\begin{array}{l}16 \mathrm{~S} \\
\text { rRNA }\end{array}$ & - & - & + & + & + & + & + & + & + & + & + \\
\hline ldh & - & - & - & + & + & + & + & + & + & + & + \\
\hline
\end{tabular}

\section{DISCUSSION}

AHPND outbreaks have emerged with mass mortality (up to $100 \%$ in some cases) during the first 20-30 days of stocking shrimp in ponds [8]. Particularly, signs of AHPND appeared on the 17th day after stocking shrimps into the pond. The highest incidence of necrosis occurred after 20-45 days, and then shrimp died in the period of 20-31 days of age [10]. Besides, although lecithin hemolysis (LDH) has been shown to be a specific gene for this bacterium from shrimp in Thailand [4], but this gene has not found in $V$. parahaemolyticus strain caused in shrimp in Vietnam. Therefore, discovery unique diagnosis method to recognize accurate spreading agents in the early period time is necessary to avoid the widespread of AHPND in cultured shrimp of Vietnam and other countries of the world. In this study, by using two different primers, one of $16 \mathrm{~S}$ rRNA gene and other of $l d h$ gene, the result of PCR reaction showed a 
specific detection of $V$. parahaemolyticus as only band existed in a well of agarose gel with the similar size of $l d h$ gen and other band of 16S rRNA gene. Besides, the precise presence of $l d h$ gen from $V$. parahaemolyticus strain caused in shrimp was determined as compare to a control $\mathrm{V}$. parahaemolyticus strain ATCC 17802. This is a defined strain only contain $l d h$ gen and absence of th and tdh genes.

Moreover, the direct factor affecting the sensitivity and specificity of a diagnosis method such as PCR is the use of suitable primers to amplify exactly to the target DNA fragment. Therefore, there have been previous several studies using two-tube nested PCR detection to detect $V$. parahaemolyticus by different primers (VpPirA and VpPirB) for recognition of two toxin genes like Pir-A and Pir-B in $V$. parahaemolyticus [7]. However, the detection threshold only stopped at the bacterial density of $10^{5}$ $\mathrm{CFU} / \mathrm{ml}$, while the detection threshold using two specific primers for $16 \mathrm{~S}$ rRNA and $l d h$ was $3.5 \times 10^{3}$ $\mathrm{CFU} / \mathrm{ml}$. This demonstrates that the use of these two primers can detect $V$. parahaemolyticus causing AHPND at 100 times lower density than the previous method.

\section{CONCLUSION}

Currently, PCR is evaluated as a technique with high sensitivity and specificity. In this study, we determined he detection threshold of PCR method with two specific primers for $16 \mathrm{~S}$ rRNA and $l d h$ was $3.5 \times 10^{3} \mathrm{CFU} / \mathrm{ml}$. Moreover, the $l d h$ gene, produced a toxin protein is responsible for capable of activating the hemolytic factor, that has not been used to diagnosis for $V$. parahaemolyticus on Vietnamese shrimps yet. On the basis of these results, we may provide an initial procedure required for precise one-step PCR method to detecting $V$. parahaemolyticus strain, which may aid to establishing efficient PCR kit targeting for diagnosis $V$. parahaemolyticus caused AHPND in shrimp of Vietnam from the breeding period until periods of increasing to the standard weight of shrimps for exporting purpose of the nurse - ponds.

\section{REFERENCES}

[1] Tran L,Nunan L, Redman R.M., Mohney LL, Pantoja CR, Fitzsimmons K, Lightner DV. Determination of the infectious nature of the agent of acute hepatopancreatic necrosis syndrome affecting penaeid shrimp. Diseases of Aquatic Organisms. 2013; 105 (1): 45-55.

[2] Dangtip S, Sirikharin R, Sanguanrut P, Thitamadee S, Taengchaiyaphum S, Mavichak R, Flegel TW. AP4 method for two-tube nested PCR detection of AHPND isolates of V. parahaemolyticus. Aquaculture Reports. 2015; (2): 158-162.

[3] Doyle MP and Beuchat LR. Food microbiology. Third edition. Washington: ASM Press. 2007

[4] Joshi J, Srisala J, Truong VH, Chen IT, Nuangsaeng B, Suthienkul O, Lo CF, Flegel TW, Sritunyalucksana K, Thitamadee S. Variation in V. parahaemolyticus isolates from a single Thai shrimp farm experiencing an outbreak of acute hepatopancreatic necrosis disease (AHPND). Aquaculture. 2014; (428-429): 297-302.

[5] Shinoda S, Matsuoka H, Tsuchie T, Miyoshi S, Yamamoto S, Taniguchi H, Mizuguchi Y. Purification and characterization of a lecithin-dependent haemolysin from Escherichia coli transformed by a Vibrio parahaemolyticus gene. Journal of General Microbiology. 1991; (137): 2705-2711.

[6] Di H, Ye L, Neogi SB, Meng H, Yan H, Yamasaki S, Shi L. Development and Evaluation of a Loop-Mediated Isothermal Amplification Assay Combined with Enrichment Culture for Rapid Detection of Very Low Numbers of Vibrio parahaemolyticus in Seafood Samples. Biol Pharm Bull. 2015; 38 (1): 82-87.

[7] Han JE, Tang KF, Tran LH, Lightner DV. Photorhabdus insect-related (Pir) toxin-like genes in a plasmid of V. parahaemolyticus, the causative agent of acute hepatopancreatic necrosis disease (AHPND) of shrimp. Diseases of Aquatic Organisms. 2015; 113 (1): 33-40.

[8] Eduardo M. Leaño và C.V. Mohan. Emerging threat in the Asian Shrimp Industry: Early Mortality Syndrome (EMS)/Acute Hepatopancreatic Necrosis Syndrome (AHPNS). Electronic newsletter-Fish Health Section/Asian Fisheries Society. 2012; (10): 1-7. 
[9] Jee Eun Han, Leone L. Mohney, Kathy F.J. Tang, Carlos R. Pantoja, Donald V. Lightner. Plasmid mediated tetracycline resistance of $\mathrm{V}$. parahaemolyticus associated with acute hepatopancreatic necrosis disease (AHPND) in shrimps. Aquaculture Reports. 2015; (2): 17-21.

[10] Le Hong Phuoc, Le Huu Tai, Nguyen Van Hao. Development of Hepatopancreatitic Necrosis Syndorme in intensive shrimp ponds in Tran De district, Soc Trang province. 2012, 268-277.

[11] Nguyen Trong Nghia, Dang Thi Hoang Oanh, Truong Phu Quoc, Pham Anh Tuan. Phân lập và xác định khả năng gây hoại tử gan tụy của vi khuẩn V. parahaemolyticus phân lập từ tôm nuôi ở Bạc Liêu. Tạp chí Khoa học Trường Đại học Cần Thơ. 2015; (39): 99-107.

\section{THIẾT LẬP QUY TRÌNH BAN ĐẦU CHO PHÁT HIỆN VIBRIO PARAHAEMOLYTICUS TRÊN TÔM NUÔI BĂNG PHƯỚG PHÁP PCR MỘT BƯỚC}

Tóm tắt. Hội chứng chết sớm (EMS) hay còn gọi là bệnh hoại tử gan cấp tính (AHPND) trên tôm đã được xác định do một chủng $V$. parahaemolyticus gây ra. Bệnh này đã mang lại sự thiệt hại lớn cho ngành nuôi tôm công nghiệp. Một trong những lý do khiến cho dịch bệnh bùng phát không thể kiểm soát là quy trình xác định tác nhân gây bệnh còn chậm và không chính xác, dẫn đến không có những biện pháp ngăn chặn kịp thời. Để cải thiện tình trạng trên và nâng cao khả năng phát hiện bệnh sớm, một quy trình PCR với hai cặp mồi chuyên biệt $16 \mathrm{~S}$ rRNA và $l d h$ được sử dụng trong nghiên cứu này để chẩn đoán nhanh tác nhân $V$. parahaemolyticus gây bệnh trên tôm với ngưỡng phát hiện là $3.5 \times 10^{3} \mathrm{CFU} / \mathrm{ml}$.

Từ khóa. Vibrio parahaemolyticus, Shrimp, Vietnam, PCR.

Ngày nhận bài: 26/06/2019

Ngày chấp nhận đăng: 22/10/2019 